\title{
Jane Smiley's A Thousand Acres: A Feminist Rebellion against Patriarchy
} Dr. Ramesh Prasad Adhikary*

Assistant Professor, Tribhuwan University, Kathmandu M. M. Campus, Nepalgunj, Nepal

DOI: $10.36348 /$ sijll.2020.v03i05.002 $\quad$ | Received: 28.04 .2020 | Accepted: 05.05 .2020 | Published: 12.05 .2020

*Corresponding author: Dr. Ramesh Prasad Adhikary

\section{Abstract}

This research article analyzes Jane Smiley's novel "A Thousand Acres", as the voice of rebellion against male exploitation and oppression of females in patriarchal society. In this research, theories of feminism; particularly the theories of Mary Wollstonecraft, Virginia Woolf, Simon de Beauvoir, and Elaine Showalter are taken as the methodological tool to interpret the novel. The research presents the struggle of females and their attempt to release themselves from the clutches of patriarchal discrimination. In the novel, the head of the family, Larry Cook, keeps the daughters in restrictions also exploits and abuses them in all ways. In it, Ginny, the daughter, who loses patience, turns aside from supporting him; defeats him in the court case; abandons him and even her own husband; starts working in a restaurant in the city; and lives with the fully pleasant and satisfied life freely there. As a qualitative research, by collecting evidences from the text as data, the tool of feminism is used to analyze them to fulfill the objective of the research.

Keywords: Feminism, patriarchy, rebellion, exploitation, other, normativity.

Copyright @ 2020: This is an open-access article distributed under the terms of the Creative Commons Attribution license which permits unrestricted use, distribution, and reproduction in any medium for non-commercial use (NonCommercial, or CC-BY-NC) provided the original author and source are credited.

\section{INTRODUCTION}

This research article is a rereading of Jane Smiley's novel, A Thousand Acres, from feminists' perspectives. The novel depicts the bitter and tragic reality of an American Midwestern family. In her novel, Jane Smiley's voice is against male hegemony which has exploited both mind and heart of the female. So Smiley discloses the vices rooted in the structure of a feudal patriarchal family. The plight of the female protagonist of the novel, Ginny, remains bounded within the patriarchal authority, an antagonistic force embodied by her father, Larry Cook. Along with such unpleasant female situation, it also speaks for the growing consciousness in women in the decades after the mid-twentieth century. Smiley raises her voice against the psychological and physical exploitation of women by challenging male superiority. Here, Ginny's action against her dominating father and the ability to live in her own decision shows the feminist rebellion against patriarchy and the woman's quest for individuality.

For the objective of the thesis, feminist perspective of analysis plays significant role. Feminist literary theory problematizes the whole human history as male history. The works and ideas of the feminist critics and theorists like Virginia Woolf, Simon de
Beauvoir, Kate Millet, Elaine Showalter, Mary Wollstonecraft, and others are included in the theoretical modality. Whatever the different feminists argue, in common, they are concerned with the issues of gender, equality and freedom of women. Feminism tries to dismantle the long established patriarchal system that subordinates and suppresses women.

Feminist critics reject the notion that females are the "others", but that they are forced to be "other". So it reveals the exploitation of women both physically and psychologically by men. It also exposes its harmful effects on women in their various potentialities. But, when they become unbearable, rebellion occurs sooner or later against it.

After 1960's women started fighting for their rights and identities and became aware of their misrepresentations in social, political, cultural, religious fields and also in the works of art and literature by the males. The novel has also the setting of the same period. As in a series, the awareness appeared in different forms: radical, liberal, materialistic, socialist, Marxist, lesbian, psychoanalytic and so on.

The novel addresses the elements like: female identity, equality, justice, freedom. The farmer, Larry Cook, not only exploits the daughter(s) physically and 
mentally, he crosses the boundary of morality by sexual exploitation, too. The two daughters, Ginny and Rose, who get reared up in patriarchal set-up, are the real victims. Except these two females, many other females' role is shown insignificant since most of the females die so young which again proves the dominance and exploitation of females by males. The death of Larry Cook's sisters, Martha and Louise in their early age, the death of Larry's own mother at 43, the death of Larry's wife so young, the absence of female members at Harold Clark's, and others strengthen to prove the argument.

Even though Ginny sounds so polite and obedient to patriarchal norms and values as she works to make Larry, her father, a successful landowner, her subversive and rebellious nature can easily be grasped from the very beginning of the novel. This female protagonist finally gets awakened through slow poison reaction. She realizes that she has been imprisoned within the domestic life. By identifying that her individuality has been dissolved within the individuality of her father, she denies her previous path of life. She realizes that the matters of equality, justice and freedom have been defined by the males in which the female perspectives get crushed. Hence the protagonist mainly resists such perspectives of patriarchy.

Ginny has been dominated throughout her life. Whereas in her younger life she was physically and sexually exploited and abused, in her adult, the domination was through silencing and misrepresentation. Unable to find out the source of her misery as she is unable to have the memory of Larry's rape and beating, Ginny couldn't resist. Ultimately as she finds out Larry as the center of power exploiting and oppressing, Ginny deconstructs the previously established ideology of domesticity by fleeing away from there. Her relocation and employment at Perkins Restaurant represents a total escape from the system and structure of farm and patriarchy. Ginny's sister, Rose, has the same plight. She is another example of patriarchal exploitation. She was beaten, raped, othered not only by her father, Larry Cook, but also by her own husband, Pete.

\section{REVIEW OF LITERATURE}

This novel has been studied different perspectives by the various critics. Olsen [1] points out the use of food in the novel to expose the novel as a story of cooking and eating varieties of food. The novel is about farming and eating of what the characters harvest in their land. The whole business of the family is an agriculture that includes both animals and plants.

Anyone who reads A Thousand Acres can't help asking this same question about the eating habits of the farmers who inhabit this Midwestern novel. Smiley's aptly named Cook family is cooking or eating, and much of the food sounds heavy and unappetizing. Most of us cringe to think of Midwest-Mex garbanzo bean enchiladas or park liver sausages canned with sauerkraut (to say nothing of tuna noodle casserole), yet these are foods that her characters prepare and expect their family and friends to eat-never mind enjoy (21).

Olsen relates food with power in the reality of domestic setting. The two daughters Ginny and Rose often seem to be cooking and serving their meals to father like in a "military punctuality at six, twelve and five on their appointed days of each week" (21). By imprisoning the daughters inside the kitchen, Larry Cook exercises the power of patriarchy.

Kellman [2] reads the novel in the similar line of Olsen. For the writer, Smiley deviates abundantly from Shakespeare's King Lear in her treatment of food. He further explains.

While the playwright offers his characters nothing to feed on but one another, the characters in A Thousand Acres are almost always either Cooking or eating; food in the language by which the author text is all the more remarkable in contrast to the fast of Shakespearean model (12).

Eating and dining play major role in the novel. Almost every major scene of the novel involves eating. Within the eating, meat plays important roles, which one could understand from Harold's organizing of pig roast in the homecoming of his son, Jess.

Kessel [3] has interpreted of A Thousand Acres as how innocent people are always dominated and oppressed. So Kessel's thesis explains the nature and manipulation of power and oppression through this novel. Similarly the realization and knowledge of being oppressed helps to combat against the domination and destroy the oppressor.

Larry Cook, the principal antagonist of Jane Smiley's A Thousand Acres remained invisible to his daughter Ginny because she had blocked out the memory of Larry's rape and beating for many years. Unable to identify him as a source of her misery, Ginny couldn't resist her father. Ultimately, however, she is able to resist and carve out a livable existence because she comes to see Larry as the center of power exerted over her (242).

Hence Kessel has read the novel from the perspective of power relation. In the beginning of the novel Larry, the father was an oppressor and Ginny, the daughter was an oppressed. But the realization and the knowledge of being oppressed help her to combat against and destroy the oppressor. 
McDermott [4] says that Larry Cook in the novel exploits both nature and human beings. On the one hand, he exploits the field to be economically successful. On the other hand, he silences, and beats and rapes his own daughters. McDermott further writes, "Larry's abuse of his land and his abuse of his daughters are connected: both are justified by a patriarchal discourse of property and implicitly condoned by his community" (395). So the novel also deals with the nature exploitation of nature, domestic violence and incest. Thus, the novel unravels the vices and draws a bleak picture of patriarchy and its domination against women.

Roiphe [5] analyzes that the novel displays the bleakness in the relationship between the family members. A father, who is considered to be respected and dignified person in family and society, himself, crosses the boundary of morality and rapes his own daughters. Roiphe further remarks:

[...] when they were wrong, the respected pillar of the community entered their yellow and pink flowered bedrooms and had sex with them. Rose remembers and Ginny forgets. On finding out the dark secret, the reader in supposed to think with satisfaction, oh yes, now it all falls into place. Ginny's passivity, Rose's hardness, their fear and anger and cruelty, their putting their father out in the furious storm-al make perfect sense (66).

The relationship between and among the characters is full of complexity. Since characters themselves are guided by their unusual nature, the complexity arises. Ginny and Rose reveal the dark secrets of their father as well as their own psychic upheavals.

All in all, this novel can't simply be taken as a tragic story; it has various subjects of love and hatred, morality and responsibility as well as incest and abuse, domination and oppression. But this research paper focuses on how the female character raises her rebellion against the patriarchy which was untouched by the previous critics.

\section{Theoretical Modality: Feminism}

Feminism is the movement of the 1960s which came as an awareness of women about male-dominated socio-cultural tendency of patriarchy. The movement brought the issues of women's rights and their recognition in the world and in intellectual domain. Feminist theories and critical practices, unfolded the marginal socio-economic status of women, and on the other, they extended enormous consciousness in women to launch collective activities for the equality and freedom of women in the society. It took about two centuries of struggle for recognition of women's cultural roles and achievements for women's social and political rights.
Throughout the history, women have been devalued as inferior, passive, kind, beautiful and emotional, whereas men have been regarded with the prestigious position of center, but women were sidelined and marginalized in the peripheral section of the society. Though there is not such natural rule and characteristics to prove hierarchy between men and women, culturally fabricated normatively of the society from ancient to the present, viewed woman as the "other" of man's "self".

Feminist critics argued and analyzed how women have been misrepresented, misinterpreted and undervalued by the whole human history. Hence the whole so called "civilized" human history is the male history. From the ancient Holy books to the modernist and postmodernist writings of the twentieth century, the role of women has been denied, controlled and negatively manipulated. They have been blamed for lacking responsibility and intelligence for they are supposed to cause all the troubles in the world. Feminists, so, term such philosophy as Phallogocentric philosophy.

In the classical times, Aristotle, the Greek philosopher asserted antifeminist ideas. Aristotle held that men are superior to women. Jostein Gaarder refers Aristotle who claimed, "A women is 'an unfinished man'. In reproduction woman is passive and receptive whilst man is active and productive; for the child inherits only the male characteristics, [. . .]" (116). The stereotypical representation that Aristotle and others did, established the hierarchy between man and woman. Such long-standing hierarchy showed men as the leaders, who imposed authority over female. The history of humans has been for the sake of males that caused to establish patriarchal norms, values and systems.

Adams [6] introduces feminism as the most successful of the political movements. For him feminism digs out that women endured double exclusion. On the one hand, many women writings were excluded from the so-called literary canon. On the other hand, the writings of males also excluded and neglected women perspective in their works. In his own words:

Feminism has recovered and revered the writings of many women excluded from the so-called literary canon and raised many voices against the canon's sexual (and racial) exclusiveness. It has shown how male writing has excluded female perspective and even actively opposed or disdained women and socalled female values (7).

Feminism hence opposes the earlier treatment done to women by patriarchy. The various theoretical positions that feminists hold in diverse fields, 
commonly work out to raise voice against the so-called canonical perspective. They have campaigned to reveal the actual causes and the processes that disdained women.

Mary Wollstonecraft [7] advocated educational and social equalities for women. For her, mind doesn't know the sex but women have been limited within the domesticity and are considered to be docile and emotional by patriarchy. She regrets and attacks the sentimental novels of her time, "Another instance of that feminine weakness of character often produced by a confined education, and is a romantic thrust of the mind, which has been very popularly termed sentimental" (398). Women were imprisoned by denying any opportunities to study the proper books; rather they were given the sentimental novels to shape the mind of the women. Hence she attacks those sentimental novels of her time for their harmful effects on women's intellectual development.

Bryson's [8] words echo that feminist thinking "seeks to understand society in order to challenge and change it" (1). Such female awakening as Bryson and others opine got impetus from the ideas of feminist critics like Mary Wollstonecraft, Kate Millet, Elaine Showalter, Virginia Woolf, Simon de Beauvoir, Sandra M. Gilbert and Susan Gubar, and so on. It further suggests the women's conscious coming out from the earlier boundaries created by male domination. Identifying their exploited situation within male culture and values, such feminists have attempted to break such traditions to reshape and reconstruct them. They have challenged earlier male-dominated psyche and practice of society by upbringing the marginalized women into center. Hence M. H. Abrams [9] analyzes:

The often-asserted goal of feminist critics has been to enlarge and reorder, or in radical instances entirely to displace, the literary canon- that is, the set of works which, by a cumulative consensus, have come to be considered "Major" and to serve as the chief subjects of literary history, criticism, scholarship and teaching (91-92).

Such rebellious nature of the feminist practices against the dominant culture, social norms and institutions aims to replace the earlier canons with the marginalized women.

Tong [10] also finds Wollstonecraft as a pioneering female heroine challenging male birth right, advocating women's equality and rationality. For Tong, she became able to liberate women from male violence and oppression by arguing against. Tong says:

[. . .] Wollstonecraft did present a vision of a woman strong in mind and body who is not slave to her passions, her husbands or children. For Wollstonecraft, the ideal woman is interested in fulfilling herself it by self-fulfillment is meant any sort of pondering to duty distracting desires than in exercising self-control (16).

Wollstonecraft never believed that women possess emotional, fragile and submissive nature only. For her, they can equally perform the reason. As patriarchy doesn't show sincerity in thinking, in turn, degrades and subjugates women, Wollstonecraft pours challenging anger.

Woolf [11] in her critical work A Room of One's Own, advocates for the equality of the women with men in the society asserting the existing sociocultural values as sexually discriminatory. Questioning the dominant male literary traditions since ancient to the present, Woolf puts foreward alternative literary conventions in which men and women get equal space to develop their literary creativity and potentiality. By challenging the prevalent norms and showing the alternative ways for the women's possibility of creativity, Woolf argues:

[. . .] when they come to set their thoughts on paper--that is that they had no tradition behind them, or one so short and partial that it was of little help. For we think back through our mothers if we are women. It is useless to go to the great men writers for help, however much one may go to them for pleasure. Lamb, Browne, Thackeray, Newman, Sterne, Dickens, De Quincey--whoever it may be-never helped a women yet [. . . (824).

With her radical feminist thought, Woolf awakens the female writers to be self-reliant and selfdependent. She is clear in her remark that if women writers knock the doors of male writers for help, male writers in stead of helping them, limit them within male ideology for the perpetuation of male normativity in literary activities.

Beauvoir [12], in her book The Second Sex (1949), has emphatically subverted the existing hierarchy between men and women. She defies the male conviction of othering women as not a natural fact but as a cultural construction. The definition of women as "other" and "the second sex" are mere fabrications of dominant patriarchal socio-cultural viewpoint. She resists, "One is not born, but rather becomes man"(7). Through this line she tends to dismantle the longstanding dichotomy prevalent between men and women. The degraded or the "othered" woman is not what she is in real sense, but what she is at present is ideologically modulated. Beauvoir intends to say the predicament of present woman as "other" is due to the omni-present patriarchal biases of the civilization which the conscious women should discard to exist themselves as independent human beings. 
Elaine Showalter through her often quoted work A Literature of their Own (1977) encourages women to create their own independent ideology so that women can free themselves from patriarchal oppression. Showalter's revision of women writers of the Victorian period adds new bricks to defy the existing male monopoly in literature. Her categorization of women writers into three phases asserts to dissect the position of women in the contemporary time.

So, feminism is also a political movement, which awakened women to bring a change in the society for women's right of liberty, equality, property, education and so on. This female awareness movement helped to change the condition of women. In a patriarchy, women were constrained by society and culture. But female awareness movement encouraged women to challenge what it means to be female in a male governed society. It tried to dismantle the conventional pattern to establish nonsexist ones. The issues like identity, self individuality and freedom became the common features for feminists, which are used to interpret this research work.

\section{Analysis of $\boldsymbol{A}$ Thousand Acres}

Jane Smiley raises the voice against patriarchy in A Thousand Acres. She draws attention of the readers about the system of family where patriarchy has dominated. Her novel, A Thousand Acres, shares many issues of feminism, and also she takes significant departure in this novel by depicting the bitter and tragic reality of an American Mid- western farming family. The plight of the female characters remains bounded within the four walls of domestic work. Ginny, the protagonist breaks such earlier boundaries created by patriarchal authority, an antagonistic force embodied by her own father, Larry Cook.

Larry Cook, a dominating patriarch, has three daughters, namely, Ginny, Rose and Caroline. Larry Cook, as an oppressive force, remains invisible as an oppressor to his daughters, especially Rose and Ginny. For many years, they seem to have blocked out the memory of Larry's beating and raping, but the revelation of the truth by Rose in the middle part of the narration, and Ginny's awakening from a long slumber caused by patriarchal domination, help Ginny to take the required initiatives of resisting her father, thwarting the whole patriarchy and its normativities, and carving out a niche in her own.

After the untimely demise of Mrs. Cook, the whole responsibility of the farm and family lies on the head of Ginny and her father's all activities get supported by her. Larry Cook decides to divide the farm among his three daughters, as Ginny and Rose are married; Caroline works as a lawyer in Des Moines; and he has been older day by day. The youngest girl, Caroline resists and is thrown out of the farm. Before dividing the farm, Larry puts a condition agreement that in the case the farm is mismanaged or abused, he can claim the land back to him. The family life proceeds ahead, and the daughters and their husbands take responsibility of Larry and the farm. The daughters, especially Ginny, neglect own feelings, ideas and the overall career by supporting the father's business routinely. Ginny confines her emotions and feelings within the walls of her heart without letting them out, as her plight of being confined within domesticity. During this long period, father exploits two daughters badly. In their young life he exploits and tortures them sexually and physically, whereas in their adulthood, he misrepresents and undervalues them.

As Ginny fails to realize and memorize the terrific activities of the patriarch, she follows the footsteps of the patriarch without doubts and disagreements. This is how she erases her self and subjectivity-- destroyed and kept silent by herself, her father and her husband, Tyler. It's her inability to identify particularly Larry as an evil source of her misery.

At the same time, in the domestic affairs, the conflicts arise between the father and other members, especially the daughters. Even if the conflicts are based on simple issues, they rise abundantly and become serious. Ginny and Rose actively perform their duties of serving the farm and the families, when their husbands, Ty and Pete respectively, work in the field reverently. Acting crazily, Larry Cook with the support of thrown out daughter Caroline files a suit in court against the daughters and the husbands on the charge of "mismanagement or abuse" of the farm because there is creation of hostility between Larry and other members and he wants to get the farm back. On the other hand, Ginny's memory of Larry's rape of her in the childhood after

Smiley digs out diverse bleak pictures from Larry Cook. As a dictator in the family, Mr. Cook is whimsical without taking a little consideration toward others' feelings and sentiments. His daughter describes his conceited nature:

We sat silently while Daddy drank his coffee then pushed back his chair and got up to go. I followed him to the door. I said, "Call me if you need anything. It'd be nice if you'd stay." I always said this, and he never actually answered but I was given to believe that he might stay next time (49-50).

On the one hand, Larry perpetuates male dominance and exploitation by keeping silent when the loving and caring Ginny offers to accompany him in his each steps of life. With his inability of understanding his own daughter's feelings, he tortures her emotionally and psychologically. 
After the demise of their mother, Ginny and Rose bear the burden of domestic life in their childhood without any disagreements, for they have to obey and agree with the patriarchal family authority. To be good farm girl, they should serve the farm, their husbands and their father without even thinking on their own. The protagonist narrator speaks, "My father, though simply declared that Rose and I were old enough to care for our sister that was that" (63).

A Thousand Acres attempts to shatter patriarchal logic of denying female perspective. Female perspectives always get drowned in the pool created by patriarchal domination. This further suggests that the female wishes, ideas, opinions, expressions, perspectives are crushed with the patriarch's disease of superiority complex. Larry, like other patriarchs, discriminates between males and females as males are considered to be bold, active, rational, and females as timid, passive, emotional and without any perspectives. Ginny is directly affected by such logic.

A Thousand Acres heavily comes upon the imposition of patriarchal normativities and their spurious effects on the innocent females. Larry Cook imposes such values and norms which the daughters take for granted. While talking with Jess Clark about Caroline's marriage, Rose reveals, "According to Daddy, it's almost too late to breed her"(10). Larry's imposition of such values portrays negative female picture that discriminates and emotionally tortures females. After all, the patriarchs impose such values for they always possess their will to power. Ginny loathes, "I was uncomfortably aware that my father always sought impossibility and taught us, using the Erickson's as his examples, to do the same to discipline the farm and ourselves to a life and order transcending many things, but especially mere whim" (46). Larry's catechism reveals two aspects. On the one hand, he is a poor moral teacher for he possesses bleakness in his morality. On the other, he is the representative of the whole patriarchal normativities in which females are taught to be disciplined for the male authority.

Patriarchy never respected female values; rather it devalues and denigrated them. The females fail to bear the excessiveness of patriarchy during the end of A Thousand Acres. With the constant resistance and foiling of patriarchal filthiness, Ginny gets victory finally by carving out a niche in herself with freedom. One of such filthinesses, patriarchy tames is its ferocious nature. Larry's posture, behavior, attitude and practice are so fearful that they bolster to suppress and impose his authority upon the daughters to get better economic status. Even though he has the biological relationship of a father with Ginny, Larry truants her and other daughters from the very beginning of their lives. They are not only the fears in themselves; they represent whole patriarchal norms and values deeply rooted in socialization as well.
Ginny's silenced voice addresses the readers:

My earliest memories of him are of being afraid to look at him in the eye, to look at him at all. He was too big and his voice was too deep. If I'd to speak to him, I addressed his overalls, his shirt, his boots. If he lifted me near his face, I shrank away from him. If he kissed me, I endured it, offered a little hug in return. At the same time his fearsomeness was reassuring when I thought about things like robbers or monsters, [. . .] (19).

Father's terrific nature affects Ginny throughout the life leaving her in a life full of pressures and tensions. Living under his domination, Ginny represses her potentiality and creativity, and thereby fails to establish herself as a creative genius in a society dominantly of males. Her remembrance of her early childhood suggests the idea that patriarchs possess the dictatorial nature that leaves females always in a life to live in fears. The creation of fears upon daughters perpetuates male domination of locating females in the domestic realm forever.

Larry Cook, as Ginny describes, in many cases, neglects the daughters' talks with him. His irresponsible nature adds the extent of psychological and emotional pains and sorrows in his own daughters. Ginny says, "We had long passed the point of eloquent silences" (177). Larry's not responding and not sharing with the daughters works as a strategy to oppress the daughters through silence. This is the manifestation of patriarchal oblivion that penetrates into the psyche and the heart badly. Harold Clark, another patriarch, opines in parallel lines with Larry Cook. His belief of keeping women away from information denigrates the whole female race. In his disagreement with Ginny, he hides the information, "If you'd have been sons, you'd understand that. Women don't understand that" (204). Larry abuses them with the ominous sounding words of sheer curse. With the black spots of such vulgar words, the patriarch exercises his authoritarian reign, on the one hand. On the other, such verbal curse not only shocks the girls, it also prepares them to take a strong reaction to subvert the whole Larry's framework of domesticity.

A Thousand Acres abundantly presents the physical violence and torture in the domestic realm. Destined to be confined within domesticity, Ginny and Rose are the butts of violence and torture. In the early part of narration, Ginny reports, "Then, one night, he broke her arm" (31). It's fearful to see Pete, Rose's husband acting crazily. His craziness comprised of wild acts, threats, insults, and sometimes the attacks as he did to Rose by breaking her arm. The load of all the household activities on the shoulder of Ginny again supports how the females are oppressed and exploited. Ginny clarifies, "But apart from cooking, cloths washing, and major housecleaning, my father needed 
little help with his domestic routine" (66). Nevertheless, there is no patience and positive response. Rather he neglects and silences her. Father's stupidity could be grasped from Rose's fury, too. She exposes, "But he did fuck us and he did beat us. He beat us more than he fucked us. He beat us routinely" (302). Rose's frustration with the father is the result of father's corrupt past.

Initially, Ginny, too, works as an agent of patriarchy as she pays too much attention to her father, who, instead doesn't respond at all. As he neglects her perspectives which could be beneficial for him, too, Ginny gets nervous. She feels, "He didn't glance at me or respond, even to dismiss me" (67). Larry Cook seems to be considering his daughters as the tools and objects to get his economic status burgeoned.

A Thousand Acres pitifully discloses that males take females as objects and commodities to fulfill and meet their ends. As the commodities and objects don't speak against the consumers, the females are also made not to express any criticism of their husbands and other males in the male dominated system. But $A$ Thousand Acres is more than any male extremities. When Ginny and Rose were teenagers and their mother was sick, Larry raped them. It was Rose who always remembered Larry's incest but Ginny forgot by repressing it. As Rose reveals, "He was having sex with you," Ginny disagrees with embarrassment (189). Ginny as a daughter couldn't believe that her father had a sex with her and she immediately responds, "He was not!"(189). But Rose tries to aware her by explaining everything about father's shameful past when Rose was thirteen, fourteen, fifteen and sixteen. Rose and Ginny talk thus:

"Because after he stopped going in to you, he started coming in to me, and those are the things he said to me, and that's what we did.

We had sex in my bed."

"You were thirteen!"

"And fourteen, and fifteen and sixteen"

"I don't believe it!" (190)

Larry's rape of his daughters in childhood proves that he tamed the corn of black seeds into his heart and nature. Moreover, he stands as an embodiment of cruel and morally corrupt persons who blinds himself by crossing the very much common barriers of humanity and relationships.

As a head of the family and as a rule maker, Larry abused the daughters by showing and applying his power with a sort of consent. Describing how he hegemonized, Rose says, "I thought it was okay if he said it was, since he was the rule maker. He didn't rape me Ginny, he seduced me [. . .]. He said he loved me" (190). Smiley's novel explains clearly how the family dominated and reigned by patriarchs is full of domestic crimes and violence against women. On the one hand,
Larry dies alive by seducing and having sexual pleasure from his own daughters. On the other, by seducing and keeping them under the illusion of love, he perpetuates his corrupt nature of will to power, which necessitates to be destroyed.

The daughters attempt to resist against such excessive father figure from time to time, but they become unable to really identify him as an evil being. Beyond this, their ideas of resistance get absorbed into hegemony by the father, Larry Cook, who becomes able to persuade his already furious daughter, Ginny. Larry says, "You know, my girl, I never talked to my father like this. It wasn't up to me to judge him and criticize his ways" (175).Ginny moves ahead by reconciling with him.

In many cases females themselves co-operate and support the wrong deeds of patriarchy. Ginny delayed and hesitated to break the walls of domesticity which led her to more tragic life under the grip of patriarchy. Ginny speaks:

No aspects of his plans were undermined, put off, questioned. How many thousands of times have I seen him in the fields, driving the tractor or the combine, steadily, with certainty from one end of the field to another. How many thousands of times has this sight aroused in me a distant, amused affection for my father [...] (136).

Ginny negates her self and assists her father's business getting nothing in return, but only the abuses, exploitation and denigration. During the time when she has to pour her bucket of anger and revolt against him, she sympathizes with her father's plight without even realizing his pretentious patriarchal self. Her thoughts illustrate her inability to identify him as an evil source of her misery and degraded condition. So in the early part of the narration she works as an agent of patriarchy which doesn't let her to free herself and to see him for what he stands.

A Thousand Acres demonstrates the ugly and corrupt nature of patriarchy that not only invites the tragedy in the lives of innocent characters like Ginny and Rose; it equally shatters the status of antagonist, Larry Cook, with the pitiful end of his life. In the background, Larry's irresponsibility and neglect of his daughters; one-sided perspective of looking at things; his exploitation of daughters verbally, morally, psychologically, sexually, emotionally and physically; his ferocious nature; his regard of females as objects and non-existent creatures; and others pile up and work a lot in the deterioration and downfall of family.

Smiley's depiction of Larry Cook as a lustful father against his own daughters also creates a sense of rebellion in the mind and heart of the readers. Hence Smiley succeeds by touching and reaching into the 
heart of readers by presenting Ginny as the dynamic character in parallel to the feelings of the readers. From the beginning of the story, Ginny presents herself as a loving, caring, and responsible daughter by repressing the sense of rebellion against the excessiveness of father. Emancipation from the life of farm and domesticity provides Ginny enough relief. Her waitressing job at Perkins Restaurant means her total escape from the imperial structure of farm and her father, but without forgetting them. Beyond so, her move to St Paul as she leaves Ty also marks the beginning of her new life of independence and selfcontrol with hope. She is satisfied with her life after she breaks the chains of patriarchy. Ginny proudly says:

The thing I loved most about the restaurant was the small talk. People bantered and smiled, thanked you, made more polite requests, chatted about early visits or the weather or where they were headed. It went on and on, day and night, pleasant and meant to create pleasantness. Eileen, the manageress, encouraged us to follow company guidelines about creating small talk, when it was absent [. ..] (332).

All kinds of tensions and conflicts lie in distance from Ginny's life after her rebellion against patriarchy. The unpleasantness she was living with daddy and Ty have been replaced by her life with the manageress, Eileen, at Perkins with satisfaction. Now, even the death news of her father with a heart attack doesn't stir her seriously for he committed all kinds of crimes with her.

Like her sister Ginny, she creates hostility with the patriarchal normativities. She joins hand in hand with Ginny as the plight of both sisters is similar--both of them were exploited morally, psychologically, physically, verbally and so on. Both of them have been beaten and raped by their own father, Larry Cook. Even when Rose takes responsibility of the father, he uses abusive words. Rose defends herself, "You can't just roll over to us. You may be our father, but that doesn't give you the right to say anything to Ginny or to me" (82). Rose revolts against the father's evil treatment done to them. Whenever and whatever the father acts crazily in the later part of the plot, Rose laughs, which suggests her ridiculing of the patriarchal vileness and corruption. In the court, when Larry told that somebody took Caroline's pulse, Ginny says, "Rose let out a bark of laughter" (320). There are numerous other instances that support Rose's rebellion against patriarchy. It's particularly because of her bad health; she dies earlier than Ginny and can't totally weaken male-centered norms. Ginny stands as a towering figure to give message to the down-trodden females under patriarchy. Hence Smiley presents Ginny as a true female heroine advocating for the liberation of all females.
Similarly Harold's wife and Jess's fiancée also died untimely. Such many instances explain that women are either made insignificant or are treated badly in patriarchy. Ginny's description of "Edith was made silent" also proves so (132). But as the females get victory over males, there's insignificance of males. Harold gets blinded in an accident caused by himself, Pete meets alcoholic accident and dies; Larry gets mad, loses the case, and dies with heart attack; Ty has a pitiable life after Ginny abandons him.

So the writer becomes successful raise the voice of rebellion to overthrow the male-centered social structure. The female heroine, Ginny got victory with many other females for that reason; Ginny not only stands as a protagonist, but also as a mouthpiece of Smiley.

\section{CONCLUSION}

After analyzing the novel, the researcher comes to the conclusion that Jane Smiley's A Thousand Acres, as a novel written with the feminist purpose, it is a rebellious voice against the exploitation of traditional patriarchy. Father Larry Cook, the traditional figure of patriarchy, is the exploiting and cause of family disintegration. He is the antagonistic force as he is irresponsible and neglected the daughters and their sentiments, whereas the daughters always took care of the whole responsibility of father's daily business. He exploited and abused the daughters in various ways-verbal, emotional, psychological, physical, sexual, moral, and so on.

Ginny was compelled to take strong reaction to overthrow the corrupt male practices. She turned aside and followed the life of freedom. Along with that, the knowledge of father's rape of her, and his accusation of mismanagement of the farm, incited in her a strong sense of rebellion against him. In this way, she revolted against the discriminatory laws of the father, sometimes with the help of her sister and sometimes alone. With Larry, all males' lives come to an end except Tyler, Ginny's husband, who is again abandoned by Ginny, thinking that no patriarchal figure lets the women to progress in their lives. All such arguments have supported Smiley's feminist purpose of sidelining the male authority and bringing the already sidelined, marginalized, and misplaced women back to the center, as Ginny, along with other females, lives a satisfied life with independence and self-decision.

\section{REFERENCES}

1. Olsen, C. C. (1998). You are what you eat: Food and power and Jane Smiley's A Thousand Acres. The Midwest Quarterly, 40: 21-24.

2. Kellman, S. G. (1995). Food Fights in Iowa: The Vegetarian Stranger in Recent Midwest Fiction. Virginia Quarterly Review 71.3 (Summer): 10-22.

3. Kessel, T. (2004). Smiley's A Thousand Acres. Explicator 62.4 (Summer): 242-243. 
4. McDermott, S. (2002). Memory, Nostalgia and Gender in Jane Smiley's A Thousand Acres. Signs 28.1 (Autumn): 389-394.

5. Roiphe, K. (1995). Making the incest scene - A Thousand Acres by Jane Smiley. Harper's Magazine, 391: 65-70.

6. Adams, H. (1992). Introduction. Critical Theory since Plato. By Adams. Ed. Orlando: Harcourt Brance Jovanovich College Publishers, 1-9.

7. Wollstonecraft, M. (1992). A Vindication of the Rights of Women. Critical Theory Since Plato. Ed. Hazard Adams. Orlando: Harcourt Brace Jovanovich College Publishers, 394-399.
8. Bryson, V. (2004). Feminist Political Theory. New York: Paragon House, n.d.

9. Abrams, M. H. (2004). A Glossary of Literary Terms. Bangalore: Prism Books.

10. Tong, R. (1989). Feminist Thought. San Francisco: West view Press.

11. Woolf, V. (1992). A Room of One's Own. Critical Theory Since Plato. Ed. Hazard Adams. Orlanda: Harcourt Brace Jovanovich College Publishers, 817-825.

12. Beauvoir, S. (1992). The Second Sex. Critical Theory since Plato. Ed. Hazard Adams. Orlando: Harcourt Brace Jovanovich College Publishers, 993-1000. 